
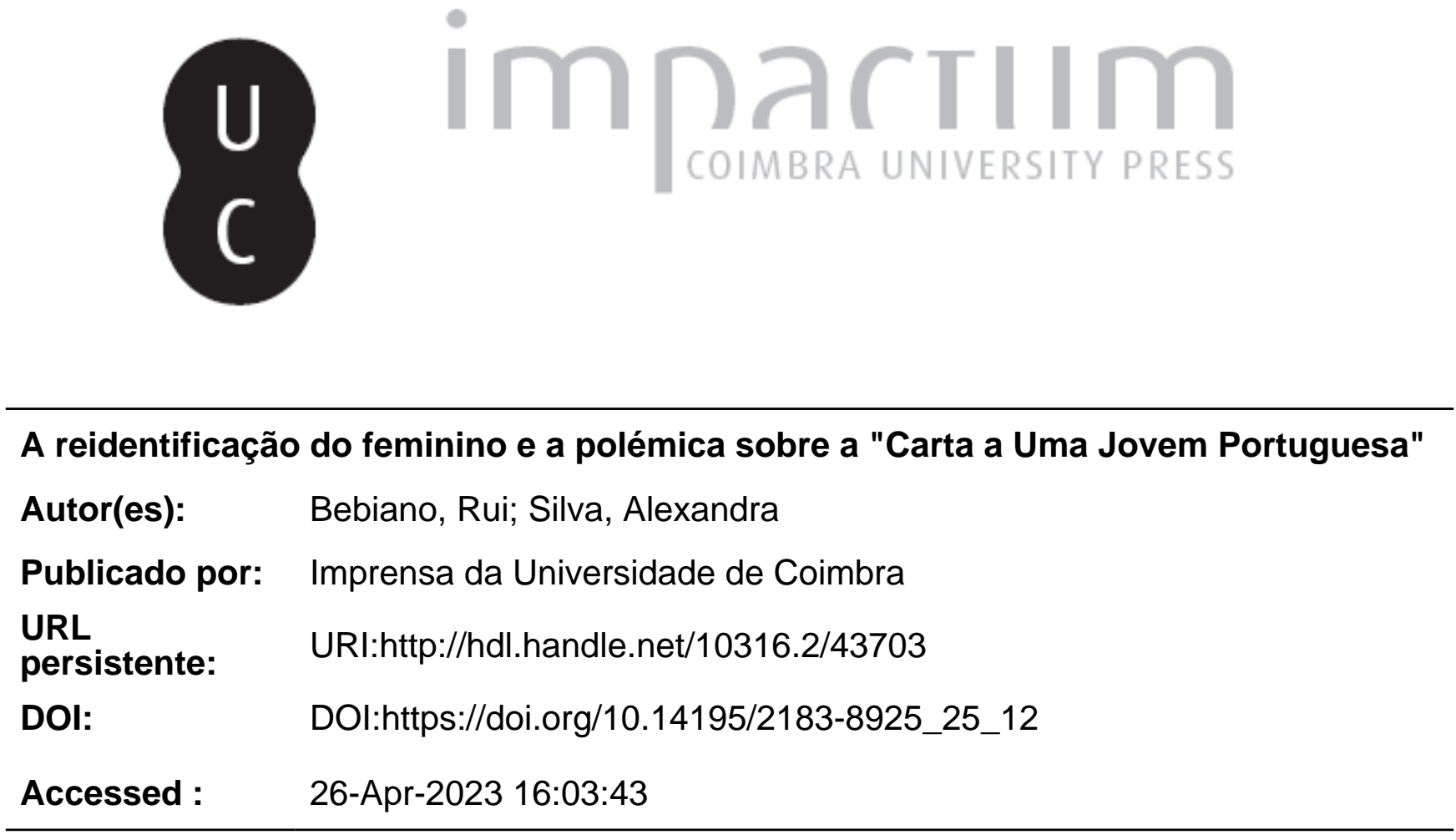

A navegação consulta e descarregamento dos títulos inseridos nas Bibliotecas Digitais UC Digitalis, UC Pombalina e UC Impactum, pressupõem a aceitação plena e sem reservas dos Termos e Condições de Uso destas Bibliotecas Digitais, disponíveis em https://digitalis.uc.pt/pt-pt/termos.

Conforme exposto nos referidos Termos e Condições de Uso, o descarregamento de títulos de acesso restrito requer uma licença válida de autorização devendo o utilizador aceder ao(s) documento(s) a partir de um endereço de IP da instituição detentora da supramencionada licença.

Ao utilizador é apenas permitido o descarregamento para uso pessoal, pelo que o emprego do(s) título(s) descarregado(s) para outro fim, designadamente comercial, carece de autorização do respetivo autor ou editor da obra.

Na medida em que todas as obras da UC Digitalis se encontram protegidas pelo Código do Direito de Autor e Direitos Conexos e demais legislação aplicável, toda a cópia, parcial ou total, deste documento, nos casos em que é legalmente admitida, deverá conter ou fazer-se acompanhar por este aviso. 

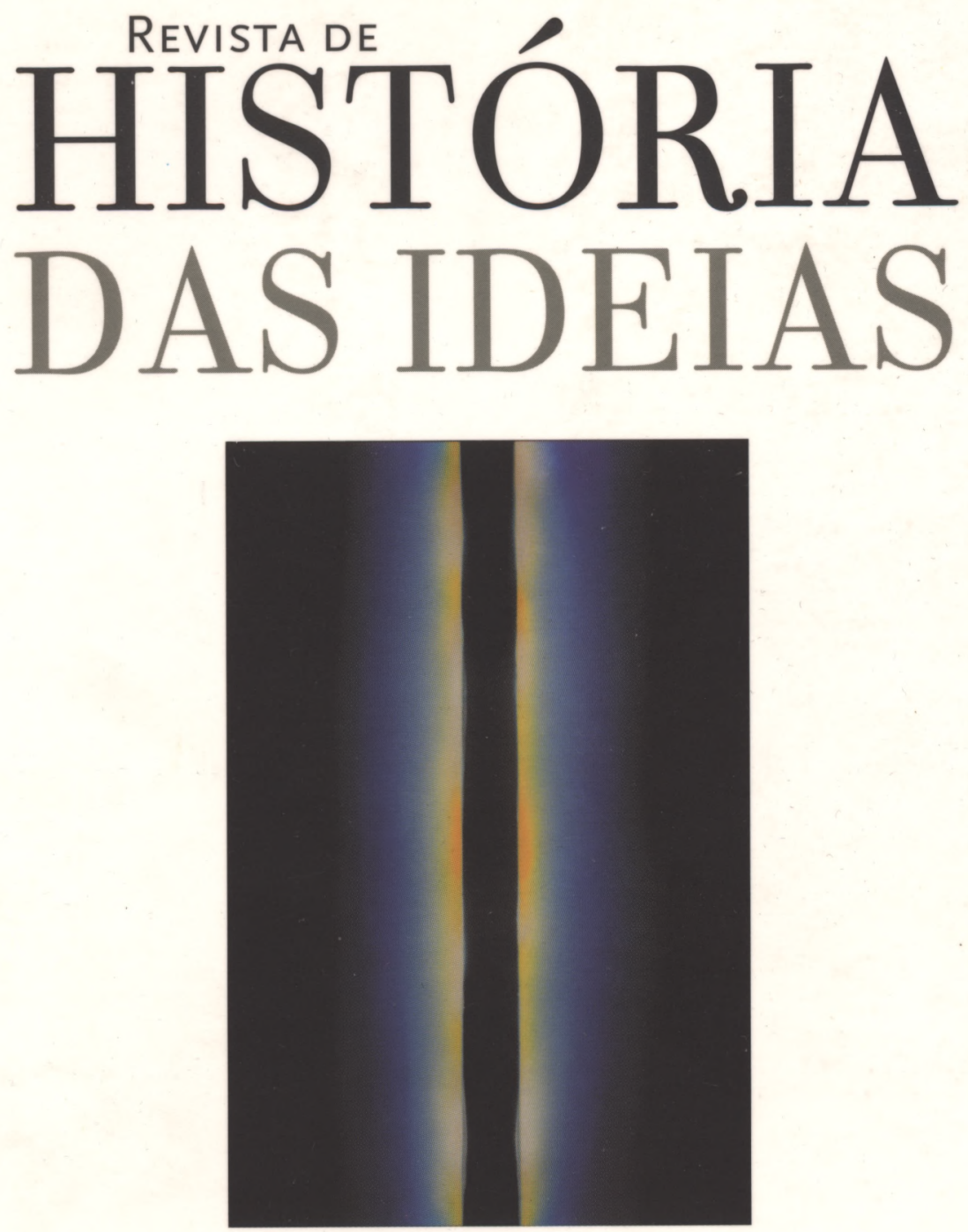

TOLERÂNCIAS, INTOLERÂNCIAS

\author{
Volume 25, 2004
}

INSTITUTO DE HISTÓRIA E TEORIA DAS IDEIAS

Faculdade de Letras da Universidade de CoImbra 
RuI BEBIANO*

\section{A REIDENTIFICAÇÃO DO FEMININO E A POLÉMICA SOBRE A “CARTA A UMA JOVEM PORTUGUESA"}

Em Abril e Maio de 1961, a controvérsia instalada em Coimbra sobre o papel da rapariga universitária no quotidiano estudantil integrou um questionamento das formas de validação do feminino e da posição que este deveria ocupar na sociedade portuguesa, em estreita ligação com as grandes transformações que a época vinha conhecendo. A querela implicou, inevitavelmente, um confronto entre concepções antagónicas e excludentes, definidas a propósito do lugar político e social da mulher. Vivida dentro de um ambiente quase inteiramente alheado das diferentes formas do debate democrático, ela foi, por este motivo, marcada sobretudo por uma grande intransigência de atitudes e de pontos de vista. Diluiu-se, porém, tão rapidamente como se formou, acabando por aparecer hoje como um momento-espaço de ensaio para o lançamento de atitudes mais consistentes e dinâmicas que viriam a ocorrer nos meios académicos anos mais tarde, durante o período marcelista.

1. Ao longo das três décadas que se seguiram ao termo da Segunda Guerra Mundial, uma intensa mobilização voltada para a acção colectiva e para a afirmação de sectores subalternizados encontrou-se no centro das mudanças processadas dentro das sociedades centrais, localizadas

* Faculdade de Letras da Universidade de Coimbra e Centro de Estudos Sociais.

** Assistente de investigação do Centro de Estudos Sociais. 
nos países mais industrializados do mundo capitalista, e das suas imediatas periferias. Novos equilibrios começaram a ser produzidos, no domínio da redefinição identitária desses grupos, mas também no que respeitava à proeminência da sua voz. A afirmação progressiva dos direitos das etnias e das confissões minoritárias, das nacionalidades marginalizadas, das mulheres, dos jovens, dos homossexuais - ou, de uma forma mais geral, de todos aqueles que, por serem aberta ou veladamente excluídos, não ocupavam um lugar central na organização dos poderes - acompanhou o crescimento fulgurante da intervenção de sectores que anteriormente se encontravam confinados a uma situação de dependência e haviam permanecido nos bastidores da mudança. Os movimentos que estes foram capazes de corporizar não se limitaram, porém, a colocar em palco novos actores conflituais, formas distintas de participação ou problemas estranhos à tradição das lutas que haviam marcado a era da afirmação do capitalismo industrial. Foram bastante mais longe, destacando a crescente inadequação das formas tradicionais de organização e de representação política para fornecerem respostas face a um conjunto de questões emergentes em sociedades cada vez mais complexas e comunicantes (Melucci, 2001).

O espaço ocupado pelas mulheres foi, neste âmbito, rapidamente destacado e integrado em ambientes de permanente tensão, aos quais corresponderam importantes alterações na redefinição do papel que ocupavam na família, no trabalho e nas actividades cívicas, bem como no domínio das práticas culturais, da vida quotidiana e da sexualidade. De facto, a partir dos anos cinquenta, a partição masculino-feminino tornou-se objecto de uma alteração rápida e profunda, vivida intensamente em ambientes urbanos marcados pelo ensaio de formulações éticas e processos de representação do mundo amplamente renovados. As feições do ser-se homem e do ser-se mulher redefiniram-se então em áreas assinaladas por uma metamorfose rápida no que respeitava às marcas prototípicas de cada um dos papéis e também à redistribuição das suas capacidades, territórios de afirmação e expectativas (Amâncio, 1998). Na base deste embate encontrou-se o intrincado processo de construção-reconstrução das múltiplas identidades de género (MacCormack, 1980). Para além do reconhecimento, determinado pela ligação entre o conhecimento científico moderno e o senso comum, da diferenciação biológica como primeiro factor da disjunção comportamental entre os sexos e da criação de estereótipos culturais a seu respeito, começava igualmente a reconhecer-se a 
importância decisiva, para esta separação, de circunstâncias de ordem social e cultural. Desta forma, os feminismos contemporâneos foram produzidos num processo de ruptura com o seu próprio passado, agora em volta da diferenciação sexual como um princípio existencial básico, negando em absoluto a exclusividade da distinção biológica enquanto "causa legítima e explicação da desigualdade" (Ergas, 1995: 591).

Ultrapassada a fase defensiva das lutas das mulheres que se seguiu à superação do combate do movimento sufragista pelo direito de voto e pela afirmação da sua presença activa nas instâncias públicas - recusando a estrita "domesticidade", mas integrando-a, ainda assim, numa concepção originalmente masculina de feminilidade (Herz, 1992) - os novos movimentos feministas, lançados a partir das décadas de cinquenta $e$ de sessenta, fizeram divergir os sectores que defendiam a "igualdade" daqueles que acentuavam a "diferença". Uns e outros rejeitavam a imagem tradicional e omnipresente de uma "feminilidade" submissa e caricaturada, tal como a sua subordinação histórica ao modelo masculino, reivindicando ao mesmo tempo a supressão das discriminações e lutando pela igualdade de direitos. Fizeram-no, no entanto, seguindo vias em larga medida opostas: uma afirmava a premência de uma utopia de igualdade entre os indivíduos, fazendo da diferença dos sexos um aspecto de certa forma secundário, enquanto a outra reclamava a absoluta especificidade do feminino e um lugar para a afirmação matricial da sua voz.

A primeira destas estratégias, de pendor igualitarista, insistia basicamente nos pontos de vista sobre a construção social da diferença avançados por Simone de Beauvoir no imediato pós-guerra. Em O Segundo Sexo, aparecido em 1949, ela considerara como uma necessidade a afirmação da identidade feminina, colocando um axioma - "não se nasce mulher, torna-se mulher" - como ponto de partida da reflexão em volta do tema. A perspectiva de Beauvoir, muito difundida na década seguinte dentro dos ambientes próximos do existencialismo sartreano, de algumas heterodoxias da esquerda e de parte significativa da juventude universitária, destacava a modelação social da atitude feminina e da sua dimensão de alteridade em relação ao arquétipo masculino. Denunciava os papéis impostos no contexto das relações sociais, produtoras da divisão dos sexos e da bipartição dos indivíduos, insistindo, ao mesmo tempo, na unidade do género humano e na liberdade, que cada uma das suas partes deveria deter, para produzir uma especificidade situada fora dos estereótipos e alheia à hierarquia vigente. A origem da lenda - hoje mais suavizada, 
mas que resistiu algumas décadas com um grande fulgor - do amor "emancipado", "livre", do par Sartre-Beauvoir, residiu em larga medida na aparente materialização, que a sua relação pessoal parecia definir, dessa mesma proposta (Monteil, 2000). Ao mesmo tempo, acreditava-se ser o social que exprimia o feminino e o masculino, diferenciados a partir de uma estrutura ainda inequivocamente controlada pelo segundo (Bauer, 2001).

De uma natureza mais essencialista, ou diferencialista, a segunda estratégia privilegiava a dissemelhança dos sexos e a revalorização identitária do feminino (Stacey, 1993). Persuadidas de que este existia "por si mesmo", embora fosse historicamente negado e sistematicamente censurado pela cultura dominante, consideraram as suas (e os seus) aderentes que ele tinha por objectivo a produção da sua própria afirmação. A especificidade feminina reivindicada era, ao mesmo tempo, carregada de evidente valor subversivo diante da organização do sistema patriarcal e da sua ordem simbólica (Picq, 1997). Foi nesta direcção que, em 1963, Betty Friedan, a psicóloga americana fundadora da National Organization for Women (NOW), atribuiu, em The Feminine Mystique, um grande ênfase à crise da identidade e à incidência de procura de ajuda clínica detectadas entre as jovens americanas de classe média do seu tempo. "Existe uma estranha discrepância entre a realidade das nossas vidas como mulheres e a imagem em relação à qual procuramos conformar-nos", observava a dado passo, para depois lançar as bases de uma abordagem que questionava as frustrações e os sintomas de infelicidade que podiam ser encontrados entre os muitos milhões de mulheres exclusiva ou principalmente educadas para se tornarem "boas esposas e boas mães" (Friedan, 1963: 43). Friedan propunha, em consequência, a procura de um sentido alternativo, mais afirmativo e autónomo, para as suas vidas (Taylor, 1992).

Porém, o processo de reidentificação pública do feminino produzia-se também do lado de fora dos grandes debates teóricos e das manifestações formais de activismo, num campo dentro do qual não era colocado na ordem do dia, de uma maneira explícita, o conflito de poder com o seu oposto. Definiam-se aí acima de tudo parâmetros fracturantes, capazes de questionarem o modelo predominante de conceber e de reconhecer o papel da mulher. Experimentado ao nível da busca de um quotidiano desconforme em relação aos padrões imperantes, pelos meados dos anos cinquenta podia ser já detectado um nítido redimensionamento do lugar e da imagem da mulher num filme francês de impacto internacional. 
Em Et Dieu... Créa La Femme (E Deus... Criou a Mulher), de Roger Vadim, nas salas pelos finais de 1956, os espectadores de muitos países assistiram ao nascimento de uma jovem actriz, Brigitte Bardot, que, no ecrã como na vida real, se começava a transformar no modelo de um tipo particular de mulher (Buurman, 1989; Baecque, 2000). Nesse processo de reformulação da imagem feminina, a BB não integrava, de forma alguma, o perfil da mulher "participativa", ou daquela "emancipada pelo trabalho", que desde o século anterior, em particular após a análise da estrutura familiar e da posição social das mulheres efectuada pelo marxismo - definida, como se sabe, a partir de $A$ origem da familia, da propriedade privada e do Estado (1884), de Engels - vinha sendo projectada pela mitografia e pela propaganda do movimento operário e socialista, apontando os fundamentos do sistema capitalista como causa última da sua condição de subalternidade. E incorporava menos ainda os contornos da "mulher livre", consciente já da sua luta identitária, liberta nos planos ético e cultural, que foi definida dentro dos meios artísticos e intelectuais que circulavam em Paris em redor de Saint-Germain-Des-Prés - simbolicamente representados, no imaginário da época, pelo ícone, longilíneo e negro, da cantora-actriz Juliette Gréco - e daí emanavam para uma parte importante do mundo. Mas a representação mediática de Bardot transformou-se, de facto, num exemplo que ajudou a romper com a concepção tradicional, submissa, remetida ao espaço doméstico, do ser-se mulher.

Outra Juliette, aqui a heroína do filme, para quem "o futuro foi aquilo que inventaram para estragar o presente", e de quem o personagem Eric Carradine afirma que "tem a coragem de fazer o que lhe apetece quando lhe apetece", surge como incarnação de uma juventude entusiástica, ávida de experiências e de prazer, materializada num corpo que se passeia à frente da câmara exibindo uma liberdade de atitudes radicalmente nova. Para obter este efeito, Vadim prestou a maior atenção aos gestos, às expressões, às marcas corporais e até mesmo aos caprichos mais pessoais da actriz, propondo uma espécie de documentário, no interior do qual a natureza (o ainda pequeno porto de Saint-Tropez, o mar, o sol, a areia da praia), o vestuário (roupas justas, entreabertas, com alguns botões convenientemente desapertados), a atmosfera (algo fútil, propícia ao lazer e à dança ao ritmo da rumba e do cha-cha-cha) se conjugavam para sublinhar a beleza diferente, inédita, claramente outra, da sua actriz. Contrariamente à expressão plástica das "estrelas de cinema" então consagradas, representativas em regra de um tipo de 
beleza e de um comportamento que se mantinham essencialmente comprometidos com os valores e a estética prevalecentes, a figura da BB evoluía enquanto "corpo verdadeiramente contemporâneo dos jovens espectadores que o olham" (Baecque, 2000: 126-7), em condições de funcionar imediatamente como modelo para os muitos milhares de raparigas que lhe copiavam a modernidade e a ousadia das atitudes, do ritmo de vida e do parecer.

Estrelas do cinema e da música popular suas contemporâneas, como Anna Karina, Jean Seberg e Françoise Dorléac, ou, entradas no meio pouco depois, Françoise Hardy e Sylvie Vartan, contribuirão igualmente, com o seu corpo e forma de estar, para a construção, dentro de um território social crescentemente dinâmico e atento à mudança, desta "feminilidade outra" que começava também a ecoar nas revistas femininas. De facto, se na viragem para a década de 1960 o tipo ideal divulgado pela Elle e pela Marie-Claire - mais ousado, comparativamente, do que o proposto em publicações americanas de grande tiragem como o Ladies' Home Journal e a Woman's Day (Walker, 1998) -, era ainda o da mulher sedutora, "objecto e sujeito do consumo" que tinha como vocação, explicitamente, "agradar e seduzir" (Elle, 1959, 53), estas figuras - como acontecera do outro lado do Atlântico com Marilyn Monroe, que filmara The Seven Year Itch (em Portugal, O Pecado Mora ao Lado) em 1955 integravam já temas e abordagens que correspondiam à materialização da nova figura da "mulher liberta", dotada de uma vida amorosa activa e variada, experimentada sem aparente má consciência, pontuada por uma iniciativa que já não era um privilégio exclusivamente masculino. Deve notar-se que, naquela altura, a entrada na vida sexual activa por parte da esmagadora maioria das raparigas europeias se mantinha ainda estreitamente vinculada ao casamento, pelo que essa sugestão de liberdade aparecia como instrumento intensamente perturbador (Sohn, 2001). Catherine Deneuve surgia, nas páginas da Elle, enquanto exemplo de "mulher emancipada", defensora da maternidade fora do casamento, ao mesmo tempo que enunciava preocupações ainda "inquestionavelmente femininas", como aquelas que tinham a ver com os cuidados diários de beleza ou as constantes transformações da moda (Veillon, 2000).

Vai ser em larga medida a redefinição da moda feminina, particularmente acentuada com a introdução do pronto-a-vestir, com a ascensão do carácter simples e funcional do trajo usado no quotidiano e com a 
irrupção flagrante da cor - que nos anos sessenta e setenta acabará por influenciar o próprio vestuário masculino - a marcar um estilo de vida associado simbolicamente à emergência da juventude como corpo social autónomo, à afirmação do inconformismo como atitude e à rápida liberalização dos costumes. "Estar na moda" não era agora, para as "raparigas modernas", copiar simplesmente o perfil senhoril e maternal das suas mães ou as formas generosas das divas do Hollywood do pósguerra. Era ser-se franzino, ao "estilo petite fille", vestir-se de forma livre e informal, ou "ingénua", contra os cânones de uma moda clássica, que se mantinha datada e acentuadamente subalternizadora da mulher. A este respeito, notou Gilles Lipowetsky que terá sido exactamente o visível boom desta moda de novo tipo a legitimar a nova visibilidade do feminino, exprimindo na sua ousadia, agora observada na rua ou repetidamente transmitida pela intervenção mediática, uma presença central, afirmativa, que até aí permanecera, em regra, alheia ao comum das mulheres (Lipowetsky, 2000: 161-5). Beauvoir, é certo, falara da ideia de elegância "como forma de escravidão", mas fizera-o ainda numa época em que a moda permanecia essencialmente nostálgica, convencional ou mesmo retrógrada (Wilson, 1985). Agora, ela tornara-se um instrumento decisivo na afirmação de um novo padrão de mulher.

A importância do movimento de reidentificação e de afirmação do feminino não excluiu, todavia, um nítido diferimento, observável tanto no curso do tempo quanto na travessia dos diferentes lugares sociais dentro dos quais foi sendo produzido. Ele surgiu, em primeiro lugar, dentro do espaço reservado de algumas elites culturais. Desenvolveu-se depois em alguns sectores urbanos, particularmente disseminados entre a juventude universitária e nas áreas sócio-culturais contíguas. E somente numa fase mais tardia, principalmente por influência dos meios de comunicação de massas, da expansão do consumismo, da difusão da publicidade e dos seus públicos-alvo, assim como do alargamento da feminização do sistema educativo, se tornou possível a sua ampliação até às classes médias.

Este foi um processo caracterizado por um ritmo enérgico, sobretudo na sua fase inaugural, que se estendeu sensivelmente até aos meados da década de 1960, porque foi forçado a desenvolver-se dentro de um clima de rejeição, ou mesmo de resistência activa, por parte daqueles sectores que materializavam a sobrevivência da ordem dominante anterior. Grupos e poderes nos quais assentavam as hierarquias estabelecidas, muitos deles 
de diferenciado sinal nos campos da definição ideológica que vinham ainda dos ambientes do período de antes da guerra, mas que partilhavam um conjunto de valores nas áreas da moral sexual e da definição estética do feminino e do masculino, foram quase sempre incapazes de aceitar ou sequer de compreender esta mudança, reconhecendo-a como potencial solvente do seu universo, do seu poder e da sua própria identidade. Daí a intolerância, a recusa, o levantamento de combativos e difíceis processos de resistência, que não foram, aliás, atributo apenas dos regimes mais autoritários e das sociedades que definiam como alicerce da sua tessitura a subalternização da mulher.

2. Pela via de comportamentos atávicos historicamente identificáveis, mas também em função da atitude que a partir dos anos trinta foi definida por Salazar e pelo salazarismo a respeito da mulher, e ainda devido ao apertado cerco cultural imposto pela censura e pela propaganda, os factores de mudança emergiram em Portugal, neste domínio, de feição bastante tímida e, de início, quase imperceptível. Conhece-se bem a forma como o edifício político e social do Estado Novo atribuía aos homens e às mulheres, dentro do quadro jurídico relativo ao exercício das actividades comuns, uma situação de inequívoca desigualdade, da qual resultava uma também diferente distribuição de papéis e a rigorosa disjunção das marcas definidoras da noção de masculino e de feminino sugeridas como perfeitas e exemplares. Na Constituição de 1933 inscrevera-se a igualdade formal dos cidadãos perante a lei, mas considerara-se também que nela deveriam necessariamente ressalvar-se aquelas que eram referidas como as "diferenças resultantes da sua natureza e do bem da familia" $\left(\operatorname{Art}^{\circ} .5^{\circ}\right)$. Sem que ao longo dos anos este princípio fosse revisto, o Código Civil de 1967 ainda definiria a inequívoca chefia masculina do agregado doméstico, condicionando à aceitação do cônjuge a participação ou a exclusão da mulher no mundo do trabalho. Esta permanecia idealmente associada ao governo da casa - aspecto no qual insistiam, pedagogicamente, tanto os programas escolares como a propaganda - e, como se esta atribuição não fosse suficientemente restritiva, impedida ainda de abandonar de livre vontade a residência conjugal, de exercer uma profissão independente, ou mesmo de atravessar as fronteiras, se para tal não possuísse assentimento escrito do pai ou do marido. $\mathrm{Na}$ área da codificação social da sexualidade, o Art $^{\circ}$. $1636^{\circ}$ declarava ainda que "a falta de virgindade da mulher ao tempo do casamento" constituía factor relevante 
para a sua anulabilidade legal, enquanto o $\mathrm{Art}^{\circ} .461$ do Código Penal referia como lícita a violação da correspondência da esposa pelo marido, aceitando-se ao mesmo tempo que o seu assassinato, quando ocorrido em situação de flagrante adultério, pudesse ser punido com pena branda.

Este conjunto de disposições funcionou, inevitavelmente, como poderoso factor dissuasor da actividade feminina no que respeitava ao contacto com um universo extra-familiar, ou, quanto muito, situado para além das ruas da exígua comunidade local ou do bairro. $O$ vislumbre de alguma emancipação em relação a este constrangimento espacial ao qual foi possível assistir em algumas áreas durante os últimos tempos da monarquia $\mathrm{e}$ nos primeiros anos da República - manifestado na presença importante de um número apreciável de mulheres em actividades da cidadania e nos lugares públicos, no reconhecimento do divórcio e da igualdade dos sexos perante a sua concretização formal, no termo do dever de obediência aos maridos, nas alterações produzidas na legislação acerca do regime de filiação e de propriedade, na abertura do mercado de trabalho em certas actividades de natureza pública - foi, aliás, desde os primeiros anos do regime salazarista, objecto de uma regressão tão rápida quanto profunda.

Às alterações introduzidas nas leis fundamentais durante os governos de Oliveira Salazar foi ainda adicionado um grande esforço de doutrinação e controlo que atravessou transversalmente o conjunto da sociedade portuguesa, marcando em profundidade os valores e os comportamentos dominantes. $O$ lugar da mulher, no seu papel essencialmente familiar, como "mãe, esposa, irmã ou filha de todos os que somos em Portugal" (Salazar, 1939: I, 317), determinava que, pelo menos na medida do que era desejável, esta permanecesse fora do universo laboral, uma vez que "o trabalho da mulher fora do lar desagrega este, separa os membros da familia, torna-os um pouco estranhos uns aos outros", e porque, como algo ironicamente escrevia pelo seu próprio punho o chefe do governo, "nunca houve nenhuma dona de casa que não tivesse imenso que fazer" (Ibidem: I, 182 e 201), devendo pois confinar-se a sua presença e actividade aos espaços considerados "próprios". Pode ser observado, na iconografia da vida quotidiana portuguesa da primeira metade do século $X X$ português, o gradual desaparecimento da figura feminina dos momentos de exposição (visível em cerimónias públicas, festividades e divertimentos, na frequência de locais de lazer, na sequência das actividades laborais), ou a sua recondução, sempre que acedia a esses cenários, a um lugar subalterno, quando não de complemento decorativo. 
A Obra das Mães pela Educação Nacional havia sido criada em 1936, estabelecendo-se no seu decreto fundador que toda a mulher deveria demandar em primeiro lugar o conhecimento das "ciências caseiras", ocupando-se, de preferência em tempo integral, com a educação dos filhos varões, "futuros homens de Portugal", e das filhas, as esposas e as mães do futuro. Dois anos depois surgirá a Mocidade Portuguesa Feminina, organizada com objectivos análogos, se bem que vocacionada para a integração das estudantes solteiras dentro do edifício orgânico do Estado Novo. Os ideais que a orientavam - completamente distintos do culto viril da força e do amor pátrio que se constituía como a principal razão de ser da secção masculina - eram praticamente os mesmos da Obra. Por sua vez, também as organizações femininas da Acção Católica Portuguesa participaram nessa tentativa de enquadramento doutrinário (Pimentel, 2000) - principalmente durante as décadas de 1930-40, antes portanto da entrada em cena de uma nova geração que a subverteu gradualmente a partir do interior, distanciando-a do regime -, fazendo-o com uma legitimidade e uma capacidade próprias, que eram fornecidas pelo seu enquadramento confessional.

$\mathrm{O}$ direito de voto foi concedido pela primeira vez às mulheres em 1931, em eleições já então fortemente condicionadas pelo governo da Ditadura, exigindo-se no entanto, para que o pudessem exercer, que fossem diplomadas com cursos superiores ou, pelo menos, com a educação secundária concluída, enquanto bastava aos homens que soubessem ler e escrever. As alterações legislativas de 1946, e mais tarde as de 1968, abriram um pouco mais essa capacidade do voto feminino, mas mantiveram ainda uma situação de efectiva desigualdade, apenas revogada depois da queda do regime. Maria Cândida Parreira, uma das três mulheres eleitas em 1934 para a Assembleia Nacional, defendera com toda a transparência, em ardente discurso público, a mulher, desprovida de voz activa, que o regime conceberia insistentemente como modelo: "a mulher-filha, a mulher-esposa, a mulher-mãe" que se deveria mostrar sempre como "companheira adorável do homem, a sua cooperadora e o seu auxílio" e teria forçosamente de se colocar, como declara, no "lugar que lhe compete" (apud Vicente, 1999: 567).

As tentativas no sentido de lançar um questionamento dos papéis femininos desta forma apontados, sugerindo a possibilidade de se poder vir a estabelecer uma igualdade em termos de direitos políticos entre os sexos, assim como a defesa da participação da mulher nas diversas áreas 
do universo do trabalho, foram numerosas e tomaram diferentes formas, ainda que desenvolvidas dentro dos condicionalismos políticos impostos pelo regime e enquadradas por uma rigidez moral enraizada em largos sectores da sociedade, particularmente entre a média burguesia e no interior do universo rural.

No processo de reconhecimento da memória desses anos tem sido feito o levantamento de muitos dos rostos, das iniciativas e dos movimentos que integraram um protagonismo gradual e sempre difícil, por parte das mulheres, no processo de resistência e oposição ao poder do Estado Novo (Gorjão, 2002). Todavia, essa actividade militante, sem dúvida corajosa, muito raramente questionou, de facto, a subordinação feminina fora do campo dos direitos políticos. Revistas como a Modas e Bordados (com o seu suplemento infantil Joaninha) e a Eva, ainda que conservadas durante bastante tempo nas mãos de mulheres ligadas à oposição ao regime, como Maria Lamas ou Etelvina Lopes de Almeida, inibiram-se sempre de questionar essa condição social tutelada e a situação específica, em Portugal, do feminino na sua relação com o masculino. Nesta linha, a Modas e Bordados, ainda em 1968 publicava editoriais com títulos tão indicativos como "Receber com Arte ou a Dona de Casa Ideal" ou "Mãe ou Esposa? Uma pergunta actual", sustentando não raras vezes o paradigma dominante da "fada do lar". Apelava-se também à resistência diante de formas de parecer cujas imagens estavam a chegar do exterior: "o passado, um passado bem português, tem muito a ensinar-nos, até mesmo no capítulo da moda!", escrevia-se (MB, 1968, 2927). E mesmo a Eva, mais atenta à mudança nos comportamentos femininos, capaz já de elogiar sinais de emancipação emergentes, como a condução de automóveis ou a vida diurna ao ar livre, não resistia aos clichés, publicando juízos bastante indicativos, como aconteceu com um artigo no qual se afirmava que a mulher "está sempre em crise, quando cresce, quando declina", que essa crise é "quase um atributo essencial da feminilidade, porque a mulher tem um sistema psicológico mais sensível e dramatiza com mais facilidade", e que, na verdade, ela gosta até de estar "um poucochinho em crise", de ter "um conflito qualquer, qualquer problema com que se ocupar" (Eva, 1962, 1088).

A Menina e Moça, revista da Mocidade Portuguesa Feminina, assegurava, nesta altura, uma posição particular de guardiã dessa feminilidade que o salazarismo reconhecia como exemplar e remetia para um lugar o mais afastado possível da praça pública, considerando que a mulher 
ocupada "a sério" com a sua casa "não tem tempo, nem paciência, para se entreter com a vida alheia" (MM, 1961,157). A pela-se mesmo à vigilância a manter - idealmente traduzida numa atitude profiláctica - perante a possibilidade de surgirem mulheres às quais as circunstâncias pudessem reduzir as condições para uma fácil incorporação no espaço doméstico. Criticam-se assim as americanas, genericamente classificadas como "vítimas de frustração mental" por viverem "torturadas pelo excesso de máquinas no lar", mergulhadas em situações de "infelicidade doméstica", que se ficariam sobretudo a dever a motivos como "a falta de conhecimentos de administração caseira, os casamentos demasiado precoces e a futilidade de espírito de muitas jovens" (MM, 1961, 165). Procura-se também dissuadir a busca de uma ocupação profissional localizada fora de casa. Em artigo surgido nos finais de 1962, aceitando-se o dilema colocado àquelas que se designavam por "raparigas de hoje" quando estas procuravam decidir sobre se deveriam permanecer em casa ou empregar-se, acabavam por sublinhar-se os argumentos a favor da primeira possibilidade, declaradamente contra a segunda. Bastava dizer-se que o emprego faria com que passasse "a não haver uma dona de casa", perdendo-se "o contacto com a família", convivendo-se dessa maneira "com muita gente mal formada, mal-educada, pervertida" e comprometendo-se "com uma vida fútil e superficial, [...] arrastada pelas tentações do luxo e das despesas, e pelas relações de acaso." (MM, 1962, 176).

As revistas de informação geral que circulavam em Portugal no início dos anos sessenta, em particular aquelas vocacionadas para um público composto essencialmente por mulheres, ainda que, em certos casos, tenham prestado alguma atenção aos novos hábitos, gostos e símbolos da "mulher moderna", faziam-no sempre com uma extrema cautela e algum esforço para não transgredirem a regra de ouro que definia a subalternidade (quando não pactuando, principalmente no plano moral, com as concepções imobilistas e imobilizantes que continuavam a assomar nas publicações e no discurso do regime). Nessa altura não era ainda possível deparar aqui com uma publicação idêntica às já mencionadas revistas francesas de referência, continuando a ser olhado com prudência e alguma estranheza, como se de algo de muito distante se tratasse, o comportamento da "mulher independente", assim designada de uma forma quase sempre irónica, frequentemente colocada entre aspas, como se a expressão se tratasse de contradictio in terminis. 
Nota-se essa cautela nas páginas do grande sucesso de vendas que foi a Crónica Feminina, publicada semanalmente a partir de 1956 e que, ao longo de décadas, acompanhará um grande número de mulheres portuguesas, de lugar social e formação cultural diversos, funcionando como um instrumento de entretenimento e de formação ligeira usado nos seus momentos livres. Como acontecia com a generalidade das publicações desta natureza, também a Crónica, mais do que falar "acerca da mulher", era acerca da feminilidade que discorria (Abranches, 1986: 390), procurando definir atitudes, comportamentos e valores reconhecidos consensualmente como próprios das mulheres e vocacionados para uma comunidade feminina encerrada ainda no seu gineceu, mantendo uma posição predominantemente conciliadora, em relação aos modelos que em sociedades mais abertas já se tinham começado a confrontar. A referência modelar era ainda a da "lindas mulheres", observadas como "personagens de contos de fadas". E mesmo as "artistas mais brilhantes e admiradas", muitas delas estrelas de cinema integradas já na vaga que agora ia emergindo, eram remetidas para um passado pessoal na qual haviam sido "como toda a gente, rapariguinhas modestas e simples" (CF, 1959, 112). Ao invés, de Françoise Sagan, a autora de Bonjour Tristesse, sempre retratada como boémia, independente e, mulher para conduzir carros de desporto com os pés nus, bastante excêntrica para os padrões convencionais em qualquer parte do mundo, dizia-se ser "mulher tão complicada que não deve valer a pena fazermos votos para que se modifique" (CF, 1959, 145). Todavia, é já notado "esse alargamento do privado/feminino ao público, essa ênfase num quotidiano que inclui o doméstico mas que o ultrapassa, essa valorização da vida da gente, que é o primeiro passo para a sua politização", como foi explicitamente reconhecido por Maria Carlota Álvares da Guerra, sua fundadora e directora (Ibidem: 394). No meio destas contradições, a Crónica Feminina acabou por se afirmar como uma publicação importante para a estruturação identitária de muitas mulheres comuns, apenas empenhadas numa maior visibilidade social do seu próprio espaço.

A Flama, revista popular de actualidades, não foi tão longe. "A mulher será sempre mulher", declarava-se ali nos finais da década de 1950, lamentando o desaparecimento das "mães educadoras" e das "irmãs que eram a sombra dessas mães", dando lugar a jovens e menos jovens, "embriagadas por uma modernidade que julgam ser mais rica" e que as vinha fazendo mudar na pose, no trajar, "tantas vezes com excesso de 
masculinização, a linguagem, e uma euforia de conquista de lugares onde o seu trabalho seja pago". Chamando-se a atenção para os deveres morais da educadora, sublinhava-se que, "para que a Humanidade caminhe com segurança, é preciso que a Mulher seja sempre Mulher" (F, 1959, 606). Será ainda nessa linha que, cerca de três anos depois, aí se irá contrapor a "doce vida amarga" apontada a Bardot (F, 1961, 709) à "dedicação à família e firmeza no casamento" aparentemente evidenciada pela actriz americana Audrey Hepburn (F, 1962, 727).

Por sua vez, as leituras que surgem na Almanaque, uma publicação que circulava sobretudo dentro dos ambientes literários, jornalísticos e estudantis $^{(1)}$, são bastante diferentes, sinalizando principalmente a atenção em relação a outros modelos. Publicada entre Outubro de 1959 e Maio de 1961, a vertigem de modernidade e de universalidade que transparecia da leitura das suas páginas não se limitava a proclamações vagas, espalhando-se por secções e artigos nos quais era uma constante a aproximação a realidades e maneiras de estar no mundo diversas daquelas que se podiam observar em Portugal. Olhava-se, com indisfarçável fascínio, os comportamentos dos mitos femininos emergentes ou em fase de afirmação diante dos seus públicos, como acontecia com a Bardot, Marilyn, Sofia Loren ou, em diferente direç̧ão, Françoise Sagan. Reportagens mensais sobre países e povos considerados "exóticos" - Afeganistão, Israel, Sahara, Pérsia, Polónia, os índios americanos, os esquimós -, artigos sobre a forma como se divertiam os habitantes de grandes cidades como Londres, Tóquio ou Nova Iorque, pequenos textos sobre actores de cinema, filósofos ou cantores contemporâneos, acompanhavam uma seç̧ão de presença constante ("As latitudes da felicidade") onde se procurava desenhar um retrato da psicologia e das formas de vida das jovens raparigas de países como a Suécia, a Inglaterra, os Estados Unidos, a Alemanha, a França ou a Itália.

Buscava-se aqui uma tipificação, por vezes excessiva e caricatural, dos traços que distinguiam vivências divergentes da experiência portuguesa. Mas, acima de tudo, dava-se uma nítida ênfase aos comportamentos - no campo da educação, da vida familiar, do casamento,

(1) Diversos testemunhos relembram que, em Coimbra, chegaram a juntar-se pequenas multidões de estudantes junto à estação do caminho-de-ferro ou a um quiosque da Praça da República, na tentativa de obterem um exemplar da revista antes que esta esgotasse. 
do emprego - que anunciavam o aparecimento de um tipo de mulher ainda raro ou mesmo inexistente em Portugal, ou então, contrariamente, que atestava os piores dos atavismos. No artigo sobre a rapariga inglesa, por exemplo, anotava-se uma situação do quotidiano - "Mãe, não faça a minha cama, saio hoje de casa!" - para explicar, e de alguma forma advogar também, uma vontade de emancipação: no fundo, aquela rapariga precisava naturalmente de "falar, conhecer mais gente", desejando ao mesmo tempo "ser independente, ter o seu quarto longe da curiosidade da família poder vir para casa à uma da noite sem ser interrogada pelos pais em pijama" (A, 1959, 2), e procurando também uma oportunidade para obter emprego e conquistar alguma autonomia económica. Já naquele que pretendia abordar o comportamento-padrão da jovem italiana se insistia, negativamente, no carácter quase militar da educação familiar - "o pai comanda o regimento e a mãe não é a amiga da filha, mas sim o seu sargento", ensinando as jovens descendentes "a fazerem 'spaghetti' e a conseguirem um marido, comportando-se como raparigas puras e estúpidas" (Ibidem, 1960,11) - e nas condicionantes de natureza jurídica e moral, sobredeterminadas pela influência do catolicismo, à afirmação da sua própria independência. Ao cuidado com uma exposição panorâmica de diferentes realidades sobrepunha-se a preocupação com a existência, e a exposição ao leitor, dos diferentes modos da condição feminina.

Já nos dois textos onde se falava, mais proximamente, das "latitudes" dentro das quais vivia a rapariga portuguesa, procurava mostrar-se um tipo particular, absolutamente sui generis dentro de portas, através do qual se tornasse possível sublinhar a diferença "entre o passado e o presente". Maria Helena e Célia C., os "casos" observados, são descritas como raparigas com hábitos de independência, que acima de tudo prezam "não ter satisfações que dar a ninguém" e se recusam a "submeter os seus caprichos aos de um marido por vezes incómodo e egoísta". Pessoas-mulheres que gostam da música de George Gershwin, dos filmes de Ingmar Bergman, dos livros de Manuel da Fonseca, bebendo habitualmente whisky ("não exageradamente") e fumando muito, "tabaco americano de preferência", achando que podem "aceitar um convite de um companheiro de trabalho, de um amigo, de um conhecimento eventual, para ir dançar a uma boîte", deitando-se tarde e andando sempre cansadas por frequentarem cinemas ou night-clubs ("Mas que quer, devemos divertir-nos, não é? A vida é tão curta e o futuro tão 
incerto.") (A, 1960, 8-9). Nada de mais afastado, portanto, da jovem caseira e talhada para o casamento que era idealizada pelo regime. Por essa altura, aliás, a Menina e Moça chegou a integrar também uma rubrica, designada "Meninas e Moças de outras latitudes", através da qual se pode presumir que esperava contrariar os textos surgidos no Almanaque, mas que se limitou à reprodução de estereótipos referentes a dois únicos lugares, a Pérsia e o Japão, nos quais a generalidade das mulheres mantinha uma posição tradicional de subalternidade (MM, 1960, 145-6).

Note-se ainda que este era também um tempo no qual um número expressivo, e sem dúvida crescente, de mulheres, particularmente de mulheres jovens, afirmava uma diferença que ia muito para além de algum apoio, mais ou menos activo mas omnipresente, às estratégias da oposição ao regime. Todavia, a essa atitude de enfrentamento num plano estritamente político, que funcionou como uma espécie de segunda linha na resistência ao Estado Novo, juntava-se agora um combate de outra natureza, situado no domínio da participação política autónoma, da defesa de uma sexualidade menos tutelada, da abertura a novos padrões no campo da moral pública e dos costumes, da cumplicidade cultural, que recusava aceitar aquilo que havia sido apontado como dicotomia, ao longo de décadas proposta pelas representações sociais dominantes, entre "as 'mulheres fáceis' e as 'mulheres decentes'" (Alão, 1990: 371).

A "problemática feminina" tinha assim entrado nas preocupações de alguns meios, mobilizando internamente um certo número de vontades e de opiniões, em consonância com as movimentações sociais de carácter emancipatório que o tempo via emergir (Marwick, 1998: 679ss). Buscava-se um esclarecimento das condições para a igualdade política, económica e social dos sexos, ao mesmo tempo que se levavam a cabo combates específicos, no sentido da eliminação das restrições discriminatórias e dos obstáculos que afastavam as mulheres de uma vida efectivamente activa e partilhada (Ergas, 1995: 587-594).

3. Integrou-se nesse momento de contradições e de mudança a polémica vivida no ano de 1961, entre os estudantes universitários de Coimbra, a propósito da publicação, nas páginas do jornal académico Via Latina, da "Carta a uma Jovem Portuguesa". A discussão então lançada plasmou contradições que se vinham revelando na sociedade portuguesa e, ao mesmo tempo, integrou reflexos que ultrapassavam largamente tanto 
a cidade quanto o próprio ambiente estudantil. A discussão sobre o lugar e as atitudes da rapariga universitária, traduziu-se num confronto de posições a propósito da condição feminina em Portugal que sobreveio dentro da comunidade estudantil, justamente o sector que se encontrava menos sujeito a constrangimentos familiares e em condições de levar a cabo a contestação do estabelecido, dentro de um espaço no qual podia fruir de um mínimo de liberdade. Porque, como salientou Rui Grácio no primeiro estudo publicado sobre o episódio, no preciso momento em que ocorreu, o núcleo crítico dessa polémica, "indiciador de culturas e estruturas mentais contrastadas", se situava, objectivamente, não tanto no domínio mais directo da política formal, sujeito a uma mais rigorosa actividade repressiva, mas "no terreno dos costumes e da moral sexual" (Grácio, 1989: 76), onde se tornava mais difícil um completo controlo. Ele continha expectativas e pontos de vista de sinal divergente, em larga medida centrados na caracterização do ser-se mulher, na sua defesa e na sua crítica.

A controvérsia ocorreu num contexto marcado pelo acentuado crescimento da população feminina universitária ${ }^{(2)}$, associado ao desenvolvimento da participação mais activa por parte de um núcleo significativo de raparigas no associativismo estudantil e em outras actividades de carácter cívico, traduzida em iniciativas como a realização de uma primeira Assembleia-Geral de Universitárias, na actuação do Conselho Feminino da Associação Académica ${ }^{(3)}$, em intervenções públicas em diversos encontros ou a autoria de variados artigos de opinião. Escreveu na altura Carlos Candal, presidente eleito da Associação Académica, que as estudantes se encontravam cada vez mais em condições de poderem oferecer um "real contributo" à acção estudantil, "ajudando à criação de hábitos enraizados de igual autoridade e responsabilidade"

(2) Em Coimbra, entre os anos lectivos de 1950-51 e 1960-61, o seu número duplicou, correspondendo já, na segunda das duas datas, a 34,5\% da população estudantil (Cruzeiro, 1979; Nunes, 2000). Em Lisboa a percentagem manteve-se sempre a mais elevada do país, chegando aos $42,2 \%$ na última data.

(3) Este proporá, no início do ano lectivo de 1960-61, um programa em quatro significativos pontos: 1) Facilitação e desenvolvimento da integração da universitária coimbrã na vida académica; 2) Aumento da projecção académica do Conselho, e defesa dos interesses e direitos das raparigas; 3 ) Organização de actividades exclusiva e predominantemente femininas; 4) Estudo da posição da mulher na sociedade contemporânea (apud Caiado, 1990: 80-81). 
perante questões que diziam verdadeiramente respeito "a toda a juventude e não apenas a uma parcela" (VL, 1961, 126). Isto é, deixando de ser a silhueta praticamente anónima por detrás da cortina, até aí cantada por uma cultura estudantil predominantemente masculina, marcada pelo "velho conceito do estudante boémio". Este vinha agora sendo reformulado, com a emergência de um outro tipo de universitário, "mais sério e preocupado com os seus problemas e com os da sociedade em que vive", como se lhe referia ainda Candal no artigo "O despertar de uma consciência" (VL, 1961, 122).

Todavia, a generalidade das atitudes sobre a inevitabilidade de um reposicionamento da condição da estudante-mulher não eram, todas elas, tão optimistas e empenhadas quanto esta na introdução de factores de mudança. Joaquim Cantante Garcia, em "Um problema momentoso: as relações entre rapazes e raparigas" (VL, 1960, 111), abordou o tema do convívio quotidiano entre os estudantes dos dois sexos, aceitando-o de uma forma cuidadosa, de acordo com um posicionamento ainda conservador na sua relação com a moral dominante, e insistindo nos "perigos" de uma "excessiva proximidade". Tal como acontecia em outros ambientes universitários, mas escorada no caso coimbrão num conjunto de vivências profundamente enraizadas na vida da urbe e da sua escola maior, uma parte significativa dos estudantes-rapazes continuava ainda a exibir uma certa forma de "virilidade ostentatória e tradicional" (Sohn, 2001: 241). Esta era comum, aliás, aos estabelecimentos universitários mais antigos, dentro da qual a bebida, o tabaco ou o jogo, e a subcultura muito conservadora que os integrava como parte do quotidiano, desempenhavam um papel de maior importância no estabelecimento de relações de convivialidade e de cumplicidades do que acontecia com o contacto regular e à luz do dia com as suas colegas. De facto, a boémia e as práticas "machistas", aplicadas a uma vivência académica do quotidiano da qual a praxe se tornou uma componente essencial ${ }^{(4)}$, tendo recuado gradualmente na vida coimbrã a partir da década de 1950, somente a partir dos finais da seguinte começariam a ser considerados como atitudes atípicas, já frequentemente condenadas.

(4) Esta foi definida através da codificação, feita de maneira gradativa e informal apenas a partir do século XIX, de comportamentos dispersos característicos do universo estudantil (Cruzeiro, 1979; Prata, 2002; Frias, 2003). 
Do lado das raparigas universitárias, porém, e apesar da afirmação gradual de um número crescente de vozes autónomas e discordantes, a atitude conformista era ainda a dominante. Quando, num "Inquérito à jovem universitária", a Via Latina questionou a opinião de estudantes que militavam em organismos culturais e desportivos associativos sobre o papel a desempenhar pela mulher no século XX, nas respostas afirmava-se ainda que "o papel da mulher é sempre o mesmo, independentemente da época em que vive: preparar-se para a sua missão de Esposa e Mãe", ou então que ela "deve acima de tudo ser aquela que, ombro a ombro com o homem, o ajuda a vencer na vida". Mas existe também quem diga que a sua presença "desempenha na sociedade de hoje uma importância que já ninguém pode olvidar", ou que ela "de maneira alguma se deve afastar dos problemas do seu tempo". No política e eticamente mais ousado dos testemunhos transcritos, a estudante Margarida Losa, do Círculo de Estudos Literários, anota mesmo que, na sua opinião, a mulher do seu século é "aquela que trabalha e que é independente economicamente, e portanto se pode equiparar ao homem, não necessitando de lhe estar submetida" (VL, 1961, 131).

O ambiente era, na realidade, marcado por um conjunto de posições, nas quais a gradual divergência era temperada por uma semântica integradora das contradições, mas disciplinada, enunciando as discordâncias de maneira sempre elaborada, cautelosa, frequentes vezes eufemística, embora nem por isso menos esclarecedora em relação à percepção evidenciada de que se vivia um tempo de rápida mudança. No longo artigo "A vocação da mulher e da universitária e a A.A.", publicado em 1959 por Manuela Formigal, depois de se insistir no "papel especialíssimo" a desempenhar socialmente pela mulher, "mãe em sentido físico, na familia", considerava-se a integração neste atributo de um outro que seria o de "mãe no sentido espiritual", o qual deveria ser consubstanciado através de um "abraço do mundo inteiro". Isto porque se tornava já claro que "no nosso século" vinha sendo pedido à mulher "um muito maior contributo actuante, uma presença muito mais actuante em todos os campos", determinado por necessidades objectivas mas nem por isso menos mobilizador. Por isso mesmo se declarava que "nós, raparigas, temos imensas possibilidades", proclamando-se em seguida que as mesmas devem ser postas "todas a render" (VL, 1959, 85). Mas no ano seguinte, no contexto da organização de uma primeira "Assembleia-Geral de Alunas da Universidade", ainda se lamentava o "desinteresse" 
e o "desapego" da generalidade das universitárias pela mais elementar militância associativa, ressalvando-se apenas a actividade, considerada excepcional, de algumas seccionistas.

As contradições que integravam esta problemática irão revelar-se em breve com maior clareza, quando da mencionada publicação, em 19 de Abril de 1961, da "Carta a uma Jovem Portuguesa", da autoria do estudante Artur Marinha de Campos (que a assinou apenas com um semi-anónimo A.). Num texto redigido, tal como o seu autor veio mais tarde a reconhecer, enquanto devaneio influenciado pela leitura fresca da obra de Beauvoir (Lourenço, 2001: 38), e que não pretendia fazer "a apologia de qualquer ideal", a fantasiada destinatária da "Carta" surge descrita como uma entre muitos milhares de raparigas sofredoras, "vítima de todos nós e de ti mesma" devido ao errado sistema social que dentro da vivência universitária as reduzia sistematicamente à passividade de quem "não sabe ver nem dizer" e a um lugar de subalternidade. A. recusa ali o papel que lhe era tradicionalmente atribuído, como homem, de "senhor a quem obrigatoriamente tens de te ligar para viveres na consideração e na segurança sociais". Declara também que essa liberdade não é igual àquela da qual a rapariga dispõe - "separa-nos um muro, alto e espesso, que nem tu nem eu construímos" - convidando os estudantes de ambos os sexos a que, em conjunto, pugnam "pela libertação através de uma mútua liberdade". Fala-se ainda, como aspecto que em breve virá a transformar-se no núcleo central do problema, da recusa de uma vivência física situada em campos apartados, da dificuldade em se poder estabelecer um quotidiano partilhado, da injustiça que é o desconhecimento habitual do "corpo" e um relacionamento construído "de espera e de rotina", mencionando-se ainda, de passagem, mas sem que na altura a referência pudesse passar despercebida, a importância do "amor que desperta entre os jovens" e a naturalidade desejável da sua "concretização sexual" (VL, 1961, 130).

A perturbação suscitada pelo artigo foi grande e imediata, despoletando uma vaga de textos de resposta e contra-resposta, publicados dentro e fora da academia: artigos, comunicados, panfletos, muitos deles impressos em tiragens que em alguns casos atingiram os milhares de exemplares (Garrido, 1996: 108-114). As organizações juvenis institucionais, de obediência política ao governo, como a Mocidade Portuguesa e a Mocidade Portuguesa Feminina, ou de dependência confessional, como a Juventude Universitária Católica e a Juventude Universitária 
Católica Feminina, irão questionar o conteúdo da carta, ainda que de forma relativamente moderada. Todavia, muitos jornais católicos regionais não se inibirão de falar, com grande aparato e uma linguagem bastante violenta, de "indignação" e de "nojo" em face de um texto que, de acordo com a sua leitura, preconizaria um "amor rastejante", um "materialismo desenfreado", uma "imoralidade arvorada em norma de conduta" (VL, 1961, 131). Ao mesmo tempo, agrupamentos juvenis de extrema-direita acusavam, como estando verdadeiramente por detrás da "Carta", "profissionais da subversão", trabalhando em prol de "planos importados de Praga e Moscovo", e materializando uma "perseverante reaç̧ão marxista" combinada com o que lhes parecia integrar também uma "conspiração maçónica" (apud Grácio, 1989). O conservador diário A Voz afirmava mesmo que "a insídia do programa do comunismo internacional para a juventude está ali, com todas as letras, com todo o despudor", considerando que a publicação que a dera a conhecer se havia transformado em "espécie de jornal obsceno, um caso da alçada da polícia de costumes" (A Voz, 1961, 12197).

Reconhecendo este impacto, a própria Via Latina dedicou ao tema um número especial, publicado apenas duas semanas depois, no qual, em editorial convenientemente destacado, fez notar que a posição do jornal apenas era definida "através de notas de redacção e editoriais designados como tal", demarcando-se pois, se bem que de um modo bastante suave, do texto de Artur Marinha de Campos. Mas a maioria dos artigos aí publicados atribuiu uma importância muito grande, absolutamente desproporcionada, àquilo que o texto declarava ou que parecia revelar, não se inibindo de criticar abertamente o seu autor pelo que efectivamente dissera e também pelo que, na opinião de tais leituras, aparentara ter dito.

Nesta linha, em "A Academia e a Moral", Augusto Ilídio Cunha sugere a "imoralidade" da autoria da "Carta", chamando a atenção "de todos os colegas cuja dignidade foi vulnerada na pessoa das próprias esposas, noivas ou namoradas" em nome da apologia de uma "escravatura do sexo". Mais moderado e argumentativo, um artigo de Dulcídia Costa tenta responder, a par e passo, a cada uma das afirmações do texto polémico, insistindo particularmente na grande importância, que diferencia em relação à possibilidade invocada por A., de um "amor dentro do casamento", pedindo que se omitam em textos públicos posições capazes de abalarem a sociedade, "uma realidade que devemos 
respeitar e na qual nos devemos integrar". Também sob a forma de missiva, A. de Jesus elogia a indignação demonstrada perante a ofensa por parte da simples estudante, a "jovem casta"(5), que designa como "pomba de soledade" e se entretém, longe das ideias dissolventes, "entre nebulosas de luar", vincando que a mulher "deve ter sempre presente a sua essência: a maternidade espiritual". Por sua vez, Anselmo de Carvalho pede à rapariga universitária que faça "vista grossa" às propostas igualitárias que sobrevoavam a academia e se mantenha "firme no seu valor", aceitando sem vacilar que "mulher é mulher, e homem é homem", sendo, tão simplesmente, "esta a diferença" (VL, 1961, 131). Em Lisboa, o jornal universitário católico Encontro dá conta também de alguma perplexidade, referindo-se a dado passo ao "erro crasso" que, na opinião de um articulista, consistia em ignorar "a radical diversidade do homem e da mulher". Aí se fez também notar, em comentário assinado por Luís Braz Teixeira e Carlos Ferreira de Almeida, que "o amor retratado por A. se baseia e reduz a um mero encontro carnal, produto de uma escolha puramente instintiva", vincando que o casamento funciona como "a garantia da validade e da frutuosidade do amor, que sem ele é anti-humano, porque não racional, e anti-social, porque anárquico e impulsivo", e comentando depois, com alguma ironia, que a sugestão daquele A., estudante de Coimbra, "se poderia resumir numa curta frase [...]: 'Jovens amorosos de todo o mundo, uni-vos!'” (E, 1961, 37).

O tema mais específico levantado por Marinha de Campos não era todavia, na altura da publicação do controverso artigo, o problema central que, neste domínio, preocupava a academia. Ele apenas integrava um outro, mais prático e imediato. No contexto de uma sociedade tradicional como era ainda a portuguesa, e dentro de um ambiente estreito, vigiado e provinciano como era dominantemente o coimbrão, colidia igualmente com a moral dominante a questão "melindrosa", na altura em debate, lançada a propósito do convívio diário entre estudantes de ambos os sexos, dentro de espaços que para o efeito se esperava que fossem criados nas faculdades. Essa era, em larga medida, a questão imediata abordada

(5) O autor referia-se à entrega ao director da Faculdade de Letras, Doutor João Providência e Costa, como mais antigo professor com assento no Senado, de um documento, assinado por cerca de 500 raparigas estudantes, que exprimiam a sua "viva repulsa" pela publicação da "Carta" (A Voz, 1961, 12196). 
na "Carta" e que os seus críticos acabaram por conduzir numa direç̧ão algo diversa. Algumas publicações conservadoras mais atentas perceberam-no rapidamente: "Cautela com os convívios!", exclamava o jornal de direita Novidades, ao mesmo tempo que $A$ Voz bradava zelosa, perante essa possibilidade: "Mães de Universitárias, alerta! Educadores e encarregados de educação, alerta! Srs. Ministros da Educação e do Ultramar, alerta!", tratando de esclarecer que tais convívios não seriam mais do que "umas festas [...] onde se passariam coisas incríveis e orgiásticas" (A Voz, 1961, 12197).

Procurando esclarecer as condições dentro das quais se desenvolvia esta incompreensão, Rui Grácio mencionou no seu estudo a afirmação de um conflito entre uma moral "cristã tradicional", da qual o salazarismo e a igreja católica se haviam tornado simultaneamente garantes e paladinos, influenciando mesmo sectores da sociedade exteriores à sua identidade política e doutrinária, e uma outra moral, de natureza "laica e moderna", a qual, principalmente entre as gerações mais novas, e sobretudo entre os estudantes universitários, estaria a recolher, de uma forma cada vez mais insistente, a influência dos ventos de emancipação, associados a novas teorias, práticas e valores, que chegavam do exterior e começavam a produzir a intenção de dar forma à alternativa (Grácio, 1989; Bebiano, 2003). Poucos anos depois do debate em redor da "Carta", o estudante católico Pedro Roseta viria ainda a falar, nas páginas do jornal Encontro, do afastamento que, desde havia algum tempo, vinha ocorrendo entre cultura profana e cultura religiosa, reconhecendo que, no interior do meio estudantil, a primeira vinha ganhando claramente terreno em relação à segunda $(E, 1967,67)$.

No âmbito deste confronto, no artigo "Em torno a múltiplos conceitos de moral. Reflexões e esclarecimento", publicado por Nicolau Vasconcelos Raposo, foram entretanto despendidas algumas reflexões sobre três concepções de ética não-cristã - "a marxista, a freudiana e a existencialista de cariz sartreano" - cujo núcleo central integrava alguns dos princípios invocados pelos defensores de uma moral mais tradicional. Assim, à ética marxista imputava-se o erro de "não conceder valor intrínseco aos conceitos morais, os quais não seriam intemporais mas sujeitos a transformações com as mudanças económicas da sociedade", definindo a presença no mundo de uma geração "não de Deus, mas do Homem". A propósito da obra de Sigmund Freud e da sua valorização da necessidade de emancipação em relação aos recalcamentos no campo da sexualidade, 
escrevia-se que "esta concepção se encontra falseada porque não atenta nas características que distinguem os animais dos homens". E por fim, sobre o existencialismo francês - difundido pouco tempo antes, nas páginas da mesma publicação, por Fernando Vilela (VL, 1961, 124), e que Eduardo Lourenço considerará mais tarde como estando na altura a afirmar-se enquanto "facto sociológico" (Lourenço, 1987: 106) - declarava-se que, "pondo de parte qualquer valor moral universal", e valorizando apenas "o indivíduo nas suas circunstâncias", dela resultaria que "deixa de haver regras, tudo é consentido", acabando, uma situação que o autor recusa abertamente, por "conferir universalidade ao conceito valorativo de liberdade". Daqui se concluía, ao articularem-se estas influências com o ambiente que havia produzido a "Carta" e com o seu conteúdo, que o essencial do seu negativismo se situava numa moral sem o norte de um objectivo último e universal, a qual acabaria inevitavelmente por conduzir, no plano do relacionamento social e da experiência da sexualidade entre homens e mulheres, "à saturação e aos aberracionismos" (VL, 1961, 131).

Perante esta forte vaga de condenação, o próprio Conselho Feminino - organismo recém-criado e integrado na actividade de uma Associação Académica que era já maioritariamente controlada por sectores estudantis em oposição às políticas do governo - se viu forçado a emitir um comunicado, no qual, demarcando-se do texto de Marinha de Campos, adiantava, de maneira conciliadora, que "dada a individualidade própria da mulher", que lhe permitia "assumir o papel específico que perante a sociedade lhe compete", se exigia que não fosse "erigida como válida qualquer escala de valores que negue esta realidade" (Ibidem). O que significava, mesmo assim, aceitar a existência de modelos diferentes acerca dos papéis desempenhados pelas mulheres na universidade e no mundo. Discutia-se, pois, aquilo em que se podia traduzir essa diferença, sendo neste contex to particularmente interessante, e sem dúvida corajoso para a época, o artigo "Encontro do Homem e da Mulher na Universidade, no Trabalho e na Vida", publicado por José Moitalina, ainda no número especial da Via Latina que se ocupou da perturbação suscitada pela "Carta".

O autor sugeriu ali uma aproximação ao lugar da jovem estudante na Universidade e na vida associativa, mas também num plano mais geral, lembrando, logo de início, que o debate se inseria numa mais vasta polémica "sobre a condição actual (necessidades materiais, culturais, profissionais, etc.) da mulher dos nossos dias perante o condicionalismo e as exigências da sociedade presente", resultante também de um movi- 
mento geral que se processava de forma inexorável, "não obstante os protestos dos que sentem a angústia de ver desmoronar-se o seu quadro de vida anterior e de se adaptarem a novas exigências que lhe são impostas de fora, [...] que lhe são impostas pela vida". Começou, desde logo, por evitar referir-se à questão, do foro da sexualidade, que indignava muito particularmente os sectores católicos e sobre a qual a maioria dos estudantes alimentava ainda numerosas dúvidas, preconceitos e tabus. Fez, em seguida, a defesa da emancipação financeira da mulher e a sua autonomização em relação às actividades do lar, ocupando um lugar cada vez mais notável no mundo do trabalho extra-doméstico. Perguntou, aliás, sobre "quem? qual mulher? que casais?" era aquela e eram aqueles dos quais então se falava. Distinguindo as lavadeiras do Mondego e as mulheres-a-dias que lavavam e cosiam nas repúblicas, lares e colégios, da mulher "que só nos nossos dias [...] começa a sentir o problema complexo e angustiante de sair de casa, de enfrentar a vida, de se preparar para a guerra do trabalho quotidiano, da contingência do ordenado mensal", lembrou a existência de um novo tipo de rapariga, a qual até ali "ficava em casa recebendo uma educação própria para uma vida doméstica", mas que agora vinha para a Universidade "receber uma preparação técnica e cultural própria para a vida profissional" (Ibidem).

Esta nova realidade configurava a quebra dos preceitos fundamentais do salazarismo a propósito dos espaços e das funções que de uma maneira ideal deveriam ser ocupados e preenchidos pelas mulheres. A actividade remunerada fora da esfera doméstica, anteriormente confinada quase exclusivamente ao trabalho rural e ao serviço doméstico, bem como a "actividades femininas" muito específicas no domínio da educação e da saúde, vinha deixando de se mostrar como uma situação excepcional, o que forçava a uma requalificação da formação profissional, bem como dos próprios padrões do relacionamento familiar e da sociabilidade em geral. O artigo de Moitalina lembrava, pois, que "o problema central" vivido na época pela mulher era "a harmonização das suas tarefas tradicionais - o lar e a educação dos filhos - com o seu trabalho profissional". De facto, o trabalho vinha-se tornando nesta altura, como bem refere Sohn, um espaço absolutamente determinante para a afirmação de um estatuto de independência da mulher, uma vez que, nos domínios da vida dentro do núcleo familiar que dependiam directamente da maternidade, ela "não podia procurar ser igual ao homem" (Sohn, 2001: 225). Sendo verdadeiro o facto de a acentuada penúria de mão-de-obra 
que se estabeleceu na Europa desde o pós-guerra até à recessão de 1974 ter determinado uma procura que facilitou bastante essa transformação (Battagliola, 2000), a alteração dos valores, das regras sociais e dos códigos jurídicos que a acompanharam foi incomparavelmente mais lenta (Witz, 1993). O que, no caso português, devido às conhecidas condicionantes estruturais determinadas pela política salazarista, ainda se tornou mais manifesto.

$\mathrm{O}$ autor do artigo sustentou de seguida a paridade de direitos e de capacidades que entendia deverem existir entre o rapaz e a rapariga - às quais já em 1959 o referido artigo de Manuela Formigal aludira (VL, $1959,85)$ - sugerindo uma "igualação" que não seria "psico-fisiológica", mas antes acentuadamente "social, cultural, cívica", falando de um caminho "lado a lado perante as mesmas situações, os mesmos problemas, a lado a lado lutando pela sua resolução" (VL, 1961, 131). E, por fim, excluiu qualquer fundamentação de natureza religiosa ou ontológica para o equacionar e a solução dos problemas colocados pelas mudanças na identificação e no relacionamento do masculino e do feminino, perspectivando-os antes "na historicidade e relativismo das condições económico-sociais e culturais envolventes" (Grácio, 1989: 78).

As dúvidas sobre o lugar da sexualidade neste ambiente de mudança foram referidas sobretudo pelos críticos da "Carta", e praticamente ignoradas por aqueles que a defendiam ou que, pelo menos, lhe toleravam as vagas insinuações ${ }^{(6)}$. Poucos anos antes, na Encontro, Fernando Marques mencionara "profundos sintomas de decadência moral" que, no seu parecer, podiam ser encontrados na vida quotidiana da população britânica, referindo que situações ali tornadas banais, como a prática do divórcio, a existência de dancings ou a liberdade de convívio entre os jovens, teriam acabado por conduzir "à prostituição e à homossexualidade" (E, 1957, 12). E agora, $A$ Voz declarava o texto de Marinha de Campos como escrito "de uma ordinarice indizível", no qual se fazia "a defesa torpíssima do amor livre e da animalesca liberdade sexual" (A Voz, 1961, 12197).

(6) Sobre o ambiente, neste domínio extremamente constrangedor, siga-se Manuel Alegre na Jornada de África: "Até o amor é clandestino, não há espaço, não há sítio, nega-se os namorados que se amam de pé, debaixo de um guarda-chuva, num recanto escondido da Sereia". (Alegre, 1989: 20). 
Dentro da academia coimbrã, Vasconcelos Raposo sublinhou também, em idêntico sentido, que "quando o homem é dominado pelo sexo, desaparece a ascese, o auto-domínio, o sentido do respeito e, por fim, toda a liberdade", uma vez que se torna "escravo das paixões" (VL, 1961,131).

Para os sectores mais avançados do meio universitário este parecia, todavia, ser ainda um problema relativamente secundário. Na verdade, era a participação mais objectivamente política das estudantes, ela sim, que se requeria no processo de afirmação do seu lugar, cabendo-lhes, como escrevia a aluna Eliana Augusta Gersão, "conhecer a sociedade em que se vive e lutar dentro dela pelo seu aperfeiçoamento" (VL, 1961, 132-133). Sobre o assunto surgiram, na altura, opiniões extremadas e combativas, nas quais a questão do convívio e a importância de uma atitude sistemática de empenho nas questões de ordem cívica se confundiam objectivamente, como se pode constatar pela leitura do artigo-manifesto escrito por Eveline Nicolau que foi publicado um mês antes da saída do texto de Campos. Ali se declarou que "em relação a todos os conceitos que se opõem às nossas legítimas aspirações, às nossas legítimas necessidades de mulheres conscientes e responsáveis", a atitude das jovens universitárias "não deve ser de submissão, mas, pelo contrário, de recusa", por tal forma, anota aí a autora, "que sejamos nós a influenciar o ambiente, e não este a dominar-nos". Para depois sublinhar, nessa mesma direç̧ão, que devem ser afastados todos os "vestígios de um passado em que homem e mulher eram dois estranhos, de vidas inteiramente compartimentadas, em que para ele havia a rua, a boémia [...], o galanteio, a piadinha apimentada [...], e para ela o recolhimento do lar, a tímida admiração pela irreverência e liberdade dele, o rubor perante as pilhérias de certo tom muito 'masculino'". O que interessava era, pois, varrer de vez "os últimos vestígios duma época ultrapassada" (VL, 1961, 128), declarando ser às próprias raparigas, e sobretudo a elas, que competiria essa tarefa.

Nos anos que se seguiram ao confronto, esta ambição será afirmada de uma forma gradual e irreversível, e, para o final da década, a larga maioria das estudantes universitárias de Coimbra integrava já, com uma presença alargada e crescentemente activa, o movimento associativo, participando dos momentos de reivindicação, circulando com uma maior liberdade e assiduidade pelos espaços comuns, partilhados agora, de forma menos constrangida, com colegas, amigos e namorados. Durante a "crise académica" de 1969, esta nova realidade emergiu já com toda a 
clareza, a contragosto dos sectores mais conservadores da academia, os quais, por essa altura, eram já claramente minoritários e estavam confinados a uma posição essencialmente defensiva.

Ao longo de todo este processo, pode assim reconhecer-se, ainda que de forma algo embrionária, o arranque, em Portugal, de uma fase de reescrita dos papéis e de afirmação de uma renovada consciência do feminino, os quais, pouco tempo antes, tendiam a separar em campos antagónicos as atitudes sociais, os modelos culturais e os comportamentos políticos protagonizados pelos homens e pelas mulheres.

Esse foi, porém, um movimento caracterizado ainda por alguma lentidão. Num estudo publicado em 1964 pela revista Análise Social, Adérito Sedas Nunes referia-se ao nosso país como integrando o que chamou de "sociedade dualista em evolução" (Nunes, 2000: 25-84), vincadamente espartilhada entre um área "tradicional", ainda influente junto do poder político e no interior do universo rural, mas já em nítida fase de involução demográfica e económica, e uma outra, tomada como "moderna", mergulhada já num incontornável processo de crescimento, apesar de ainda só poder ser detectada em espaços urbanos e em sectores sociais restritos, nomeadamente aqueles que tinham, ou conservavam, alguma relação com a vida universitária e a sua cultura própria. Aqui, a influência de uma abertura ao exterior - articulada, por essa época, com fenómenos novos, como a vaga de emigração para alguns países do ocidente europeu, a intensificação do comércio externo ou o impacte do turismo de massas e da penetração da televisão - foi produzindo as condições para o aparecimento de novas afinidades familiares, laborais e sociais, bem como para a aceitação de um "influxo renovador" produzido por valores, atitudes e códigos de conduta que em boa parte chegavam do exterior. Estas transformações manifestaram-se dentro do território universitário sob formas diversas, tendo sido num primeiro momento uma das mais nítidas, sem dúvida, aquela que passou pela renovação do lugar da rapariga-estudante e pela sua autonomização como tipo socialmente destacado, com uma identidade própria e capacidade de intervenção, o que se tornava particularmente importante numa época e num meio dentro dos quais o estudante do ensino superior, futuro "doutor" ou "engenheiro" a curto prazo, continuava a possuir como expectativa um lugar assegurado de prestígio e de poder. 
Fronteiras eram vencidas e novos lugares estavam a ser ocupados na geografia dos papéis sociais e da participação na cidadania reconhecida pelas duas metades, a feminina e a masculina, em sociedades que se encontravam num processo de mutação rápida e profunda (e a portuguesa não constituía excepção, mesmo tomando em linha de conta as características de isolamento que ainda a marcavam profundamente). Todavia, para que esta mudança pudesse ocorrer de feição efectiva e duradoura, foi necessário aceitar ainda como instrumental o papel detido por algumas correntes de opinião, como as de inspiração marxista, as quais, centrando o seu esforço em fundamentos de natureza meta-histórica, com uma grande dificuldade de adaptação às propostas dos grupos e das causas que delas se haviam aproximado num momento tardio - e o combate das mulheres foi uma delas - as quais, não surgindo como centrais na sua leitura do mundo em movimento, permaneciam algo laterais na sua acção. A dimensão anti-disciplinar dos movimentos sociais nascidos ou reconstruídos no decurso dos anos sessenta virá justamente a integrar, como componente fundamental, a recusa dessa atitude objectivamente excludente e uma valoração dos combates que, pela sua transversalidade social e heterodoxia de princípios, preenchiam novos objectivos e procuravam também responder a novos problemas (Stephens, 1998; Melucci, 2001). Como aconteceu, sem dúvida, com os movimentos e formas de opinião que visavam recolocar o lugar da mulher.

A deriva, mas também a força, das lutas pela afirmação dos seus direitos e da sua identidade própria passou, em larga medida, pelo reconhecimento do um percurso autónomo, múltiplo, quase sempre ao arrepio da dominação masculina e das causas que foram apropriadas e enunciadas, a partir do pós-guerra, pela generalidade das correntes mainstream de organização, opinião e representação política. Por Portugal, no momento e no contex to aqui observados, passou também esse trajecto.

\section{Referências bibliográficas}

Publicações periódicas: Almanaque (A), Crónica Feminina (CF), Elle, Encontro (E), Eva, Flama (F), Menina e Moça (MM), Modas e Bordados (MB), Mundo Ilustrado (MI), Novidades (N), Via Latina (VL), $A$ Voz.

ABRANCHES, Graça; MOREIRA, João Paulo, (1986). "Sobre a Crónica

Feminina", in A Mulher na Sociedade Portuguesa, vol. 2. Coimbra, Instituto de História Económica e Social, 385-400. 
ALÃO, Ana Paula (1990). "Amor e Sexualidade: mudanças de comportamento", in Portugal Contemporâneo. Dir. António Reis. Lisboa, Publicações Alfa, 367-380 ALEGRE, Manuel (1989). Jornada de África. Lisboa: Publicações Dom Quixote. AMÂNCIO, Lígia (1998). Masculino e Feminino. A Construção Social da Diferença. Porto: Afrontamento.

BAECQUE, Antoine de (2000). “Des Corps Modernes. Filles et petites filles de la Nouvelle Vague", in Les Annés 68. Le Temps de la Contestation. Dir. Geneviève Dreyfus-Armand et alii. Paris, Complexe, 125-139.

BATTAGLIOLA, Françoise (2000). Histoire du Travail des Femmes. Paris, La Decouverte.

BAUER, Nancy (2001). Simone de Beauvoir, Philosophy and Feminism. New York, Columbia University Press.

BEBIANO, Rui (2003). O Poder da Imaginação. Juventude, Rebeldia e Resistência nos Anos 60. Coimbra, Angelus Novus.

BUURMAN, Gon; CHAPKIS, Wendy (1986). Beauty Secrets: Women and the Politics of Appearance. New York, South End Express.

CAIADO, Nuno (1990). Movimentos Estudantis em Portugal: 1945-1980. Lisboa, Instituto de Estudos para o Desenvolvimento.

CRUZEIRO, Maria Eduarda (1979). “Costumes estudantis de Coimbra no século XIX: tradição e conservação institucional". Análise Social, vol. XV (60),795-838.

ERGAS, Yasmine (1995). "O sujeito mulher. O feminismo dos anos 1960-1980", in História da Mulheres (Vol. 5 - O Século XX). Dir. Georges Duby e Michelle Perrot. Porto, Afrontamento, 583-611.

FERREIRA, Virgínia (2000). "Sexualizando Portugal: Mudança Social, Políticas Estatais e Mobilização Social das Mulheres", in Portugal Contemporâneo. Org. António Costa Pinto. Madrid, Sequitur, 180-212.

FRIAS, Aníbal (2003). "Praxe académica e culturas universitárias em Coimbra", Revista Crítica de Ciências Sociais. Vol. 66, 81-116.

FRIEDAN, Betty (1983). The Feminine Mistique. New York, Dell Pub.

GARRIDO, Álvaro (1996). Movimento Estudantil e Crise do Estado Novo. Coimbra 1962, Coimbra, Minerva.

GOMES, Joaquim Ferreira (1987). A mulher na Universidade de Coimbra. Coimbra, Livraria Almedina.

GORJÃO, Vanda (2002). Mulheres em Tempos Sombrios. Oposição Feminina ao Estado Novo. Lisboa, ICS.

GRÁCIO, Rui (1989). "Moral e Política na Academia de Coimbra. Crónica documentada de uma polémica no dealbar dos anos 60", Vértice. II série, 15, 69-85. 
HERZ, Nicole (1992). Opposition to Female Suffrage in the United States [URL: www.tcr.org/tcr/essays/CB_Female_Suffrage.pdf]

LIPOWETSKY, Gilles (2000). A Terceira Mulher. Permanência e Revolução do Feminino, Lisboa, Instituto Piaget.

LOURENÇO, Eduardo (1987). "Situação do Existencialismo", Heterodoxias II. Lisboa, Assírio \& Alvim, 105-123.

LOURENÇO, Gabriela; COSTA, Jorge; PENA, Paulo (2001). Grandes Planos. Oposição Estudantil à Ditadura. 1956-1974. Lisboa, Associação 25 de Abril.

MACCORMACK, Carol; STRATHERN, Marilyn (eds.) (1980). Nature, Culture and Gender. Cambridge, Cambridge University Press.

MELUCCI, Alberto (2001). A Invenção do Presente. Movimentos Sociais nas Sociedades Complexas. Petrópolis, Vozes.

MONTEIL, Claudine (2000). Os Amantes da Liberdade A aventura de Jean-Paul Sartre e Simone de Beauvoir no século. Mem Martins, Inquérito.

NUNES, Adérito Sedas (2000). Antologia Sociológica. Selecção e prefácio de Maria Filomena Mónica. Lisboa, Imprensa de Ciências Sociais.

PICQ, Françoise (1997). "Un homme sur deux est une femme: les féministes entre égalité et paritéé ", Les Temps Modernes. 593, 219-237.

PIMENTEL, Irene Fulsner (2000). História das Organizações Femininas no Estado Novo. Lisboa, Círculo de Leitores.

PRATA, Manuel Alberto Carvalho (2002). Academia de Coimbra (1880-1926). Contributo para sua história. Coimbra, Imprensa da Universidade.

SALAZAR, António de Oliveira (1939), Discursos e Notas políticas. Vol. I: 1928-1934. Coimbra, Coimbra Editora.

SOHN, Anne-Marie (2001), Âge Tendre et Tête de Bois. Histoire dês Jeunes dês Années 1960, Paris, Hachette.

STACEY, Jackie (1993). "Untangling Feminist Theory", in Introducing Women's Studies. Dir. de Diane Richardson e Victoria Robinson, London, MacMillan Press, 49-73.

STEPHENS, Julie (1998). Anti-Disciplinary Protest. Sixties radicalism and postmodernism. Cambridge, Cambridge University Press.

TAYLOR, Joan Kennedy (1992). Reclaiming the Mainstream: Individualist Feminism Rediscovered. Buffalo, Prometheus Book.

VEILLON, Dominique (2000). "Corps, beauté, mode et modes de vie : de 'plaire' au 'plaisir' à travers les magazins féminins (1958-1975)", in Les Annés 68. Le Temps de la Contestation. Dir. Geneviève Dreyfus-Armand et alii. Paris, Complexe, 163-177. 
VICENTE, Ana (1999). "Situação das Mulheres", in Dicionário de História de Portugal. Vol. VIII. Porto, Figueirinhas, 565-571.

VICENTE, Ana (2002). Os Poderes das Mulheres. Os Poderes dos Homens. Lisboa, Gótica.

WALKER, Nancy A. (1998). Women's Magazines 1940-1960: Gender Roles and the Popular Press. New York, Palgrave MacMillan.

WILSON, Elizabeth (1985), Enfeitada de Sonhos. Lisboa, Edições 70.

WITZ, Anne (1993). "Women at Work", in Introducing Women's Studies. Dir. de Diane Richardson e Victoria Robinson. London, MacMillan Press, 272-302. 